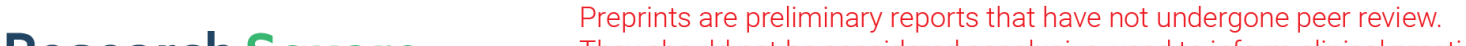 \\ They should not be considered conclusive, used to inform clinical practice, \\ or referenced by the media as validated information. \\ The rate of Seismic deformation in the Gulf of Aqaba as inferred from moment tensor summation
}

Sattam Almadani ( $\square$ sattam.madani@yahoo.com )

Full paper

Keywords: Focal mechanism, magnitude-frequency distribution, Moment-magnitude relationship, Seismic moment rate, Strain tensor, Velocity tensor, Principal stresses, Gulf of Aqaba

Posted Date: March 24th, 2020

DOl: https://doi.org/10.21203/rs.3.rs-18454/v1

License: (c) (i) This work is licensed under a Creative Commons Attribution 4.0 International License. Read Full License

Version of Record: A version of this preprint was published at Studia Geophysica et Geodaetica on October 1st, 2020. See the published version at https://doi.org/10.1007/s11200-020-1028-7. 


\title{
THE RATE OF SEISMIC DEFORMATION IN THE GULF OF AQABA AS INFERRED FROM MOMENT TENSOR SUMMATION
}

\author{
Sattam Almadani* \\ Geology and Geophysics Department, College of Science, King Saud University, Riyadh 11451, Kingdom of Saudi Arabia
}

\begin{abstract}
The main goal of this study is to quantify the rate of seismic deformation in the Gulf of Aqaba. The moment tensor summation technique based on the seismicity data, for all available historical and instrumental data (1900-2019), and reliable fault plane solutions was used to calculate the size and the shape of deformation. For the period from 1900 to 2019, the seismicity data was used to calculate the seismicity parameters (representing by the GutenbergRichter and moment-magnitude relations) and the spatial extent of the deformation zone. The fault parameters of forty-four earthquakes, having moment magnitudes range from 3.2 to 7.2 , were used to construct the moment tensor summation and subsequently to calculate the rate of seismic deformation. The calculations showed that a predominant shear deformation acting in the Gulf of Aqaba is taken up by extension in a direction of $N 40.8^{\circ} \mathrm{E}$ at a rate of $0.83 \pm 0.21$ $\mathrm{mm} / \mathrm{yr}$. and compression in a direction of $\mathrm{N} 131.6^{\circ} \mathrm{E}$ at a rate of $0.32 \pm 0.05 \mathrm{~mm} / \mathrm{yr}$.; reflecting the Gulf of Aqaba is undergoing from shear deformation accommodated along a strike-slip fault. The obtained results exhibited that the present-day deformation in the Gulf of Aqaba is acting by the interaction of relative tectonic motions among African, Sinai and Arabia plates.

Keywords: Focal mechanism, magnitude-frequency distribution, Moment-magnitude relationship, Seismic moment rate, Strain tensor, Velocity tensor, Principal stresses, Gulf of Aqaba
\end{abstract}

\section{Introduction}

The Gulf of Aqaba is one of the most spectacular earthquake-prone areas of the transform plate boundary in the world, formed by the interaction of relative tectonic movements between

\footnotetext{
* correspondence: $\underline{\text { sattam.madani@yahoo.com }}$
} 
African, Arabian, and Sinai plates. It represents as a transition zone that connects the Dead Sea Fault (DSF) of sinistral offset and the Red Sea of rifting process (Quennell, 1959; Freund et al., 1968, 1970; Bartov et al., 1980; Garfunkel, 1981; Salamon et al, 1996). The Gulf of Aqaba is structurally formed from three basins that are typically bounded on the east and west by longitudinal faults. The main fault is characterized at several locations by left-handed stepover that continues as a parallel fault with a sinistral displacement, generating the structure of pull-apart basins. The previous studies used different datasets indicate that the movement initiated at $~ 14-11 \mathrm{Ma}$ (Freund et al.,1970; Garfunkel, 1981). The slip rate based on geodetic estimations showed a left-lateral deformation at $4.4 \pm 0.3 \mathrm{~mm} / \mathrm{yr}$. along the Gulf of Aqaba-Dead Sea transform fault (Mahmoud et al., 2005), while the sinistral motion of 5.6 $\pm 10 \mathrm{~mm} / \mathrm{yr}$. was determined for the southernmost segment of the Aqaba fault (McClusky et al., 2003). The low recurrence rate of earthquakes of magnitudes greater than 6 implied total horizontal slip rate of 2 to $4 \mathrm{~mm} / \mathrm{yr}$. is accommodated north the western side of the Gulf of Aqaba (Makovsky et al., 2008). The kinematic study of Jestin et al. (1994) indicates that the tectonic process produced a seismogenic zone characterized by extensional-to-shear deformation showing that seismicity occurs in the Gulf is due to the relative plate motion between African, Arabian and Sinai Plate. The relative plate motion between the aforementioned plates is shown in Figure 1.

The Gulf was experienced by a number of earthquake sequences that are clustery distributed in space and time, revealing localization of crustal deformation within the earth's crust. The seismicity that occurred in the Gulf of Aqaba from 1964 to 2019 is shown in Figure 1. The 1995 earthquake sequence, Mw 7.2, was the most destructive earthquake occurred in the Gulf since the turn of this century (Salamon et al., 1996). The spatial distribution of the earthquake sequences revealed that the seismic activity is clustery distributed in space and time revealing crustal deformations localize within the earth's crust in the Gulf. Focal mechanisms of moderate-to-large size earthquakes exhibited normal to strike-slip faulting mechanisms 
(Abdel-Fattah et al., 2006, Abd el-all and Badreldin, 2016, Almadani 2017). The seismic tomography of El Khrepy et al. (2016) depicted no stretching is continued from the Red Sea, implying a transition of crust types towards the north.

Knowledge of the velocity and strain tensors of seismogenic deformation is an essential tool for determining the seismic hazard of an active region. An estimate of seismic strain tensor is used to characterize the active crustal deformation in a seismogenic zone, that is the most essential tools for the seismic hazard assessment. Integration between Geological, Geodetic and Seismological data is a crucial way to obtain more stable and constrained estimates of the strain rate. As a matter of fact, the geologically derived strain rate depends on the quantitative geological data for the study area, which is not always available. While Geodetic strain takes into account the total value of the active deformation, it is unable to distinguish the seismic components from the aseismic ones. However, it is still unclear whether geodetic data can be extrapolated to longer time periods owing to the short instrumental record (Papanikolaou et al. 2005). Owing to the limitations in geological and geodetic observations, the seismological approach remains particularly interesting to quantify the rate of active crustal deformation using all available historical and instrumental data.

Different approaches can be applied to estimate the seismic deformation (Jackson and McKenzie, 1988, Kiratzi, 1991; Papazachos and Kiratzi, 1992; Kiratzi, 1993; Kiratzi and Papazachos, 1995). In this study, the method developed by Papazachos and Kiratzi (1992) is used to quantify the seismic deformation in the Gulf of Aqaba by means of a summation of seismic moment tensor. The method is based on the availability of seismicity parameters, focal mechanism solutions, the maximum magnitude and dimension of the seismogenic zone.

\section{Geologic and Tectonic settings}


The Gulf of Aqaba is one of the two bifurcations of the northernmost end of the Red Sea that represents the NE-SW geologic trend in Egypt. The movements are younger in the Gulf of Aqaba from the Gulf of Suez. The Gulf of Aqaba is formed in the Early or Middle Miocene orogeny (Bosworth et al., 2005) due to the oblique drift of the Arabian plate combined with an opening component of the Red Sea. The Late Miocene motion is associated with a shear stress regime, characterized by an extension in the direction of $\mathrm{N} 40^{\circ} \mathrm{E}$ and a compression in the direction of $\mathrm{N} 130^{\circ} \mathrm{E}$, which produced the left-lateral motion between the Arabian plate and the Sinai subplate. Since the end of the Miocene the faulting due to an E-W extension, which indicates a rotation of the regional stress pattern in the vicinity of the transform fault. The deformation along the Dead Sea Transform is characterized by $105 \mathrm{~km}$ sinistral slip in the direction of $\mathrm{N} 25^{\circ} \mathrm{E}$ that are mostly accompanied with an extensional component (Freund et al., 1968; Garfunkel,1981). Landsat images revealed that the deformation is extended to only 20 $\mathrm{km}$ wide to the north and $60 \mathrm{~km}$ wide to the east area around the coastlines of the Gulf (Lyberi, 1988).

Structurally, the Gulf of Aqaba is $180 \mathrm{~km}$ long and $25 \mathrm{~km}$ wide formed from three successive pull-apart basins (Garfunkel, 1981). These basins are connected by en echelon strike-slip faults striking of $\mathrm{N} 20^{\circ} \mathrm{E}$ (Ben-Avraham, 1985) accompanied by a small amount of extension that is still in debate (Ben-Avraham and Zoback, 1992). Based on geophysical data, the mantle is presumably upwelling in the southern part of the Gulf (Ben-Avraham, 1997), while the southern part of the Gulf, the velocity structure can be compared to the oceanic crust through a transitional zone in the central part that is considered as the most active tectonic part of the Gulf of Aqaba (Ben-Avraham and Tibor, 1993), while the continental crust structure is dominant in the northern part.

Although a large earthquake magnitude of 7.2 has occurred in the Gulf, the review of seismic activity implies that the seismicity rate in the Gulf is normal to low. The seismic 
activities in the Gulf represent the upper crust seismogenic zone of $15 \mathrm{~km}$ thickness bounded between focal depths of 5 to $20 \mathrm{~km}$. The fault plane solutions exhibited a dominant shear stress regime with subhorizontal plunges for the maximum compressive stress $(\sigma 1)$ and the minimum compressive stress $(\sigma 3)$, which oriented to the northwest and northeast, respectively (Hussein et al., 2013).

\section{Data use}

The hypocenter parameters of past earthquakes are comprehensively collected to be used to compile a homogeneous catalog. Owing to the geographical location of the Gulf of Aqaba, a homogeneous catalogue was compiled from various earthquake catalogues published by the Institute of Petroleum Research and Geophysics (IPRG), Abou Elenean (1997), the Egyptian National Seismological Network (ENSN), the Saudi Geological Survey, and International Seismological Center (ISC). For this purpose, a unified moment magnitude was performed. The dataset of focal mechanisms, that were used for estimating the seismic strain rate, comprises forty-four earthquakes in the moment magnitude ranges from 3.2 to 7.2 collected from different sources. Besides the data published at the regional and international seismological centres, the dataset includes the focal mechanism solutions published by Badawy and Horváth (1999), Hofstetter et al. (2003), Salamon et al. (2003), Hussein et al. (2013), Mohamed et al. (2015), Abdel-Aal and Badreldin (2016), Badreldin et al. (2019), and Ali and Badreldin (2019). The focal mechanism solutions are shown in Figure 2 for earthquakes of fault plane parameters listed in Table 1.

\section{Methodology}

We followed the method of analysis developed by Papazachos and Kiratzi (1992) that based on the formulations of Kostrov (1974), Molnar (1979) and Jackson and McKenzie 
(1988). The formula represents the average strain-rate tensor, as defined by Kostrov (1974), is given as follows;

$$
\dot{\varepsilon}_{i j}=\frac{1}{2 \mu V} \dot{M}_{o} \bar{F}_{i j} \quad i, j=1,2,3
$$

where $\mathrm{V}$ is the volume of the seismogenic deforming region and $\mu$ is the rigidity modulus. The quantity of the annual scalar moment rate $\left(\dot{M}_{o}\right)$, as defined by Molnar (1979), is based on the scalar moment of the largest earthquake observed in the zone $\left(\mathrm{M}_{\mathrm{o}, \max }\right)$, the constants of the Gutenberg-Richter ( $a$ and $b$ ) and magnitude-moment ( $c$ and $d$ ) relations as follows,

$$
\dot{M}_{o}=\frac{A}{1-B} M_{o, \max }^{(1-B)}
$$

where $A=10^{\left(a+\frac{b d}{c}\right)}$ and $B=\frac{b}{c}$. On the other hand, the elements of the moment tensor $\left(\bar{F}_{i j}\right)$ is a function of the strike, dip, and rake of the focal mechanism solution. The moment tensor is calculated using the equations defined by Aki and Richards (1980). We introduce the elements of the symmetric moment tensor $\left(\bar{F}_{i j}\right)$ for completeness of this paper, as given by,

$$
\begin{aligned}
& \vec{F}_{11}=-\left(\sin \delta \cos \lambda \sin 2 \phi+\sin 2 \delta \sin \lambda \sin ^{2} \phi\right) \\
& \vec{F}_{12}=(\sin \delta \cos \lambda \sin 2 \phi+1 / 2 \sin 2 \delta \sin \lambda \sin 2 \phi) \\
& \vec{F}_{13}=-(\cos \delta \cos \lambda \cos 2 \phi+\cos 2 \delta \sin \lambda \sin \phi) \\
& \vec{F}_{22}=\left(\sin \delta \cos \lambda \sin 2 \phi-\sin 2 \delta \sin \lambda \cos ^{2} \phi\right) \\
& \vec{F}_{23}=-(\cos \delta \cos \lambda \sin \phi-\cos 2 \delta \sin \lambda \cos \phi) \\
& \vec{F}_{33}=(\sin 2 \delta \sin \lambda)
\end{aligned}
$$

where $\varphi, \delta$, and $\lambda$ is the strike, dip, and rake of the focal mechanism solution. Finally, based on the relations developed by Jackson and McKenzie (1988), the elements of the velocity tensor (Uij) normal and parallel to the zone boundary as well as vertically are calculated using the following equations: 
$U_{11}=\frac{1}{2 \mu I_{2} I_{3}} \dot{M}_{o} \vec{F}_{11}, \quad U_{12}=\frac{1}{2 \mu I_{1} I_{3}} \dot{M}_{o} \vec{F}_{12}, \quad U_{13}=\frac{1}{2 \mu I_{1} I_{2}} \dot{M}_{o} \vec{F}_{13}, \quad U_{22}=\frac{1}{2 \mu I_{1} I_{3}} \frac{\sum_{n=1}^{N} M_{22}}{T}, \quad U_{23}=$ $\frac{1}{2 \mu I_{1} I_{2}} \dot{M}_{o} \vec{F}_{23}$, and $U_{33}=\frac{1}{2 \mu I_{1} I_{2}} \dot{M}_{o} \vec{F}_{33}$

Where $\boldsymbol{I}_{1}$ and $\boldsymbol{I}_{2}$ are the length and the width of the deforming volume, respectively, and $\boldsymbol{I}_{3}$ is the thickness of the seismogenic layer. Since $\vec{F}_{\mathrm{ij}}$ is calculated using the relations of Aki and Richards (1980), a rotation of the in the reference system is necessary.

The Monte Caro simulation technique is used, as proposed by Papazachos and Kiratzi (2992), to analyze the detailed errors in the strain rate and velocity tensors. The influence of tensor $\vec{F}_{\mathrm{ij}}$ introduced little uncertainties on the magnitude of deformation relative to the influence of seismic moment rate $\dot{M}_{o}$. On the other hand, the direction of deformation influences by the errors in tensor Fij while the errors in $\dot{M}_{o}$ have no effect on errors are introduced by seismic moment rate. The errors in seismic moment rate can be measured by evaluating the errors in contents ( $\mathrm{a}, \mathrm{b}, \mathrm{c}$, and $\mathrm{d}$ ) derived from the adopted magnitude-frequency distribution and the Ms-Mo relationship.

\section{Results}

The quantify the rate of crustal deformation, prior estimates for the Gutenberg-Richter and momentmagnitude relationships should be performed. For this purpose, the homogeneous catalogue of a unified moment magnitude was used. The seismicity in the Gulf of Aqaba revealed an observed maximum moment magnitude of 7.2 and the moment-magnitude relation of constants $c=1.5 \pm 0.04$ and $\mathrm{d}=15.37 \pm 0.2$, as determined by Hofestetter (2003). Figure 3 shows the Gutenberg-Richter relation of seismicity parameters $a=6.3 \pm 0.02$ and $b=0.98 \pm 0.09$ for earthquakes of moment magnitudes greater than $3.6 \pm 0.14$, as determined in this study. Based on the constants derived from the adopted magnitudefrequency distribution and the constants of the moment-magnitude relationship, the scalar seismic moment rate $\left(\dot{M}_{o}\right)$ is computed to be $1.074 \mathrm{E}+24$ dyne $\mathrm{cm} / \mathrm{yr}$. 
The dimensions (length $\mathrm{I}_{1}$, width $\mathrm{I}_{2}$, and thickness $\mathrm{I}_{3}$ of the deformed seismogenic zone were calculated from the distribution of seismicity using a simple least-squares technique (Papazachos and Kiratzi, 1992). The seismogenic zone has an extent of nearly $170 \mathrm{~km}$ alongstrike extent $\left(I_{1}\right), 30 \mathrm{~km}$ along the width $\left(I_{2}\right)$, and thickness $\left(I_{3}\right)$ of $15 \mathrm{~km}$, as determined from a depth-distance cross-section of the hypocenters. The azimuth with the north of the deformation zone is of $20^{\circ} \mathrm{NE}$. The shear modulus is used to be $3.0 \mathrm{E}+11$ dyne $\mathrm{cm}$. Applying the equation 3 , the components of the tensor $\vec{F}_{\mathrm{ij}}$ representative for the Gulf of Aqaba are as follows:

$\begin{array}{ccc}-0.18 & 0.26 & 0.09 \\ 0.26 & 0.51 & 0.09 \\ 0.09 & 0.09 & -0.33\end{array}$

The corresponding eigenvalues of the tensor $\vec{F}_{\mathrm{ij}}$ are the following:

$\begin{array}{ccc}\lambda^{o} & \varphi^{o} & \delta^{o} \\ 0.615 & 71.0 & 6.9 \\ -0.242 & 337.5 & 26.7 \\ -0.373 & 174.3 & 62.3\end{array}$

where $\lambda$ is the eigenvalues, $\varphi$ is the azimuth, and $\delta$ is the plunge. The eigenvalues are ordered to represent the tensional, null, and compressional axes of double couple focal mechanism. The eigenvalues of tensor $\vec{F}_{\mathrm{ij}}$, are deviated from the identical values $(1,0$, and -1$)$, reflecting the diversity of focal mechanism solutions in the deformation zone between normal to strike-slip ones. Based on the fault plane solutions used in the present analysis, the eigensystem of the tensor $\vec{F}_{\mathrm{ij}}$ revealed that the Gulf of Aqaba is undergoing from shear stress regime with a minor extensional component accommodated by the ENE extension $\left(\mathrm{N} 71^{\circ} \mathrm{E}\right)$ and almost NNW-SSE compression (N174.3E); obtaining an average focal mechanism, of strike $188.1^{\circ}$, dip $44.7^{\circ}$, and rake $-50.3^{\circ}$, that indicates an oblique extension, where both dip-slip and sinistral strike-slip displacements are combined. 
Subsequently, using the values of the scalar seismic moment rate and the tensor $\vec{F}_{\mathrm{ij}}$ computed above, the components of both the strain rate tensor $\left(\dot{\varepsilon}_{i j}\right)$ and the velocity tensor (Uij) were calculated by applying equations 1 and 4 . The components of the strain rate tensor are as follows:

$$
\begin{array}{ccl}
-0.478 & 0.697 & 0.230 \\
0.697 & 1.359 & 0.241 \times 10^{-7} / \mathrm{yr} . \\
0.230 & 0.241 & -0.881
\end{array}
$$

while the components of velocity tensor are:

$$
\begin{array}{lll}
0.334 & 0.562 & 0.090 \\
0.562 & 0.174 & 0.044 \mathrm{~mm} / \mathrm{yr} \\
0.090 & 0.044 & -0.132
\end{array}
$$

The eigensystem of the velocity tensor is given as follows:

$\begin{array}{ccc}\lambda o & \varphi o & \delta o \\ 0.83 \pm 0.18 & 40.8 & 5.7 \\ -0.14 \pm 0.03 & 96 & -80 \\ -0.32 \pm 0.05 & 131.6 & 8.1\end{array}$

The dominant mode of seismic deformation is about $1.359 \mathrm{E}-7 / \mathrm{yr}$. as expressed by $\dot{\varepsilon}_{22}$ component of the strain rate tensor and indicates an extensional movement of the east and the west sides. It is noteworthy to observe the considerable vertical movement at a rate of $0.88 \mathrm{E}-7 / \mathrm{yr}$. that expresses as crustal thinning. The eigensystem of the corresponding velocity tensor revealed that the Gulf of Aqaba is undergoing from shear deformation accommodated by the $\mathrm{NE}$ extension $\left(\mathrm{N} 40.8^{\circ} \mathrm{E}\right)$ at a rate of $0.83 \pm 0.18 \mathrm{~mm} / \mathrm{yr}$. and almost $\mathrm{NW}-\mathrm{SE}$ compression $\left(\mathrm{N} 131.6^{\circ} \mathrm{E}\right)$ at a rate of $0.32 \pm 0.05 \mathrm{~mm} / \mathrm{yr}$.; reflecting a predominant left-lateral strike-slip fault of strike $176.1^{\circ}$, dip $80.2^{\circ}$, and rake $-1.7^{\circ}$. The standard deviations associated with the solution was calculated using the approach proposed by Papazachos and Kiratzi (1992), which considers the possible random errors of the model parameters by means of a generator of Gaussian noise type. For new random parameters generated in each iteration are used to estimate the alternative values of $\dot{M}_{o}$, and the corresponding strain and velocity tensors. The random values within the 
mean standard errors were used to obtain reasonable uncertainties where an error factor of the constants of magnitude-frequency distribution and the Ms-Mo relationship account up to about 3.

\section{Discussions and conclusions}

The technique followed in this study, seismic moment tensor summation, is useful to deepen our understanding about the deformation caused by seismic slips along plate boundary zones. The Gulf of Aqaba represents the southernmost segment among the Dead Sea Transform Fault that characterized by shear deformation accompanied by extensional stress regime leading to the formation of pull-apart basins. The most intense seismicity occurs in the Gulf of Aqaba show a direct relation to the northward motion of the Arabian plate relative to African plate with an anticlockwise rotation of $6^{\circ}$ angle at a rate of $1 \mathrm{~cm} / \mathrm{y}$ (Girdler, 1966; Garson and Krs, 1976). Moreover, the anticlockwise rotation of Sinai subplate towards the northwest with respect to the Arabian plate plays a key role in the present-day tectonic deformation in the Gulf of Aqaba.

Using the moment tensor summation technique, the magnitude and vector direction of deformation characterizing the studied zone were quantified. A total number of 60 fault plane solutions, the adapted magnitude-frequency distribution, and the moment-magnitude relationship were used to estimate the seismic strain tensor magnitudes and directions. The scalar moment rate by the earthquakes occurred in the studied area from 1964 to 2019 is equal to $1.074 \mathrm{E}+24$ dyne $\mathrm{cm} / \mathrm{yr}$. The deformation is accommodated by maximum compressive stress, $\sigma_{1}$, has a shallow plunge of $8.1^{\circ}$ towards the $\mathrm{N} 131.6^{\circ} \mathrm{E}$ direction and minimum compressive stress, $\sigma_{3}$, has a shallow horizontal plunge of $5.7^{\circ}$ toward the $\mathrm{N} 40.8^{\circ} \mathrm{E}$ direction; corresponding to a coupling of extensional to stress regime activated an approximately left-lateral strike-slip focal mechanism of normal component (strike $176.1^{\circ}$, dip $80.2^{\circ}$, and rake $-1.7^{\circ}$ ). The results 
obtained from the present study reveal a deformation pattern related to the relative plate motion between the African and Arabian plates as well as the key role that is playing by the relative motion of Sinai subplate. Owing to the relative motions between the continental plates in the region, the seismic deformation in the Gulf of Aqaba region is consistent with the tectonic process that coupled prevailing tensional stress and the left-lateral strike-slip movement. Based on the analysis of 46 earthquakes having moment magnitudes in the range of 3.2 to 7.2 , focal mechanism solution solutions alternated between strike-slip and Normal faulting mechanisms, which reflect various processes for the transition from rifting, in the north Red Sea, to continental transform, in the Gulf of Aqaba and the Dead Sea. It is noteworthy that the seismic tomography analysis of El Khrepy (2016) revealed that no observation of oceanic crust is transited into the Gulf. The majority of the focal mechanism solutions reveal a strike-slip movement with a normal component, which could be attributed to the NNE left-lateral strikeslip faults parallel to the Gulf. Normal faulting mechanisms represent 9 earthquakes, which reflect the transverse NNW-SSE faults that form the boundaries of the major basins in the Gulf (Salamon et al. 2003).

The results of the velocity tensor obtained from this study reflect that the present-day stress regime is a left-lateral strike-slip deformation with a reverse component accommodated along the NNW-SSE trending plane, that consistent relatively with the results deduced from the stress tensor inversion by Hussein et al (2013) that exhibited maximum compressive stress, $\sigma_{1}$, has a plunge of $19^{\circ} \pm 11^{\circ}$ towards the $\mathrm{N} 145^{\circ} \pm 13^{\circ} \mathrm{E}$ direction and minimum compressive stress, $\sigma_{3}$, has a shallow horizontal plunge of $1^{\circ} \pm 5^{\circ}$ toward the $\mathrm{N} 56^{\circ} \pm 15^{\circ} \mathrm{E}$ direction. Alternatively, the results obtained by Ali and Badreldin (2019) revealed a significant difference with maximum compressive stress, $\sigma_{1}$, has a plunge of $23^{\circ} \pm 15^{\circ}$ towards the $\mathrm{N} 357^{\circ} \pm 46^{\circ} \mathrm{E}$ direction and minimum compressive stress, $\sigma_{3}$, has a shallow horizontal plunge of $8^{\circ} \pm 2^{\circ}$ toward the $\mathrm{N} 90^{\circ} \pm 49^{\circ} \mathrm{E}$ direction. The uncertainties indicate the difference between the results. By 
repeating the calculations using datasets of focal mechanisms published by Hussein et al. (2013), individually, it is seen that seismic deformation in the Gulf of Aqaba is characterized by an average extension of $0.95 \pm 0.2 \mathrm{~mm} / \mathrm{yr}$. in a mean direction of $\mathrm{N} 35.6^{\circ} \pm 7.2^{\circ} \mathrm{E}$.

The analysis of GPS measurements in the area revealed that the rate of crustal deformation of the Gulf of Aqaba is $3.2 \mathrm{~mm} / \mathrm{yr}$. north and $1.8 \mathrm{~mm} / \mathrm{yr}$. east (Mahmoud et al., 2005; Reilinger et al., 2006). The slip rate retrieved from the geodetic measurements showed a left-lateral deformation at $4.4 \pm 0.3 \mathrm{~mm} / \mathrm{yr}$. along the Gulf of Aqaba-Dead Sea transform fault (Mahmoud et al., 2005), while the sinistral motion of 5.6 $\pm 1 \mathrm{~mm} / \mathrm{yr}$. was determined for the southernmost segment of the Aqaba fault (McClusky et al., 2003). The low recurrence rate of earthquakes having magnitudes greater than 6 implied total horizontal slip rate of 2 to $4 \mathrm{~mm} / \mathrm{yr}$. is accommodated along the Gulf of Aqaba (Makovsky et al., 2008). It is noteworthy that four events of magnitudes greater than 6.5 occurred within time span up to 2000 years that means a maximum velocity of about $4 \mathrm{~mm} / \mathrm{yr}$. for the cumulative displacement of about $8 \mathrm{~m}$ (Klinger et al., 1999). The velocity derived from regional kinematic plate tectonics models is about 7.5 to $9.5 \mathrm{~mm} / \mathrm{yr}$. (e.g., see Jestin et al., 1994); emphasizing a normal level of seismicity compared with what could be expected from the plate tectonics models. The results of this study quantify a small rate of active crustal deformation in the Gulf of Aqaba characterizing by an extension rate of $0.83 \pm 0.18 \mathrm{~mm} / \mathrm{yr}$. along the direction of $\mathrm{N} 40.8^{\circ} \mathrm{E}$ and a thinning deformation of $0.32 \pm 0.05 \mathrm{~mm} / \mathrm{yr}$. along the direction of $\mathrm{N} 131.6^{\circ} \mathrm{E}$. The dominant mode of seismic deformation in the Gulf of Suez is expressed by extension at a rate of $0.008 \mathrm{~mm} / \mathrm{year}$ in the direction of $\mathrm{N} 28^{\circ} \mathrm{E}$ with a small crustal thinning of $0.0034 \mathrm{~mm} / \mathrm{year}$ (El-Nader and Hussein, 2018); indicating small seismic deformation relative to that occurs in the Gulf of Aqaba.

To this end, the dominant mode of seismic deformation in the Gulf of Aqaba shows an east-west extension and a north-south compression at $0.83 \pm 0.18 \mathrm{~mm} / \mathrm{yr}$. and $0.32 \pm 0.05 \mathrm{~mm} / \mathrm{yr}$., respectively. Moreover, a small vertical movement at a rate of $0.13 \mathrm{~mm} / \mathrm{yr}$., corresponding to 
crustal thinning, was observed. The results obtained imply that the interaction of relative tectonic motions among African, Sinai, and Arabia plates is responsible for the present-day crustal deformation that is activated in the Gulf of Aqaba. It is noteworthy to mention that the Late Miocene motion that associated with a shear stress regime of an extension, in the direction of $\mathrm{N} 40^{\circ} \mathrm{E}$ and compression in the direction of $\mathrm{N} 130^{\circ} \mathrm{E}$, produced a left-lateral motion between the Arabian plate and the Sinai Peninsula (Lyberis, 1988).

\section{Acknowledgments}

This work was supported by King Saud University, Deanship of Scientific Research, College of Science Research Centre. Generic Mapping Tools developed by Wessel and Smith (1991) was used for data mapping.

\section{Authors' contributions}

The author read and approved the final manuscript.

\section{List of abbreviations}

Not applicable

\section{Funding}

This work was supported by King Saud University, Deanship of Scientific Research, College of Science Research Centre.

\section{Availability of data and materials}

The datasets used and/or analyzed during the current study are available from the Saudi Geological Survey, Saudi Arabia. 


\section{Competing interests}

The author declares that he has no potential conflict or competing interests.

\section{Author Details}

Department of Geology \& Geophysics, King Saud University, Riyadh 11451, Kingdom of Saudi Arabia

\section{References}

Abdel-Aal, Kh., Badreldin, H., 2016. Seismological aspects of the 27 June 2015 Gulf of Aqaba earthquake and its sequence of aftershocks. Journal of Seismology, 20(3), pp.935-952.

Abdel-Fattah, A.K., Hussein, H.M. and El-Hady, S., 2006. Another look at the 1993 and 1995 Gulf of Aqaba earthquakes from the analysis of teleseismic waveforms. Acta Geophysica, 54(3), pp.260-279.

Aki, K., Richards, P.G., 1980. Quantitative seismology: theory and methods (p. 13). Freeman.

Ali, S.M. and Badreldin, H., 2019. Present-Day Stress Field in Egypt Based on a Comprehensive and Updated Earthquake Focal Mechanisms Catalog. Pure and Applied Geophysics, 1-32.

Almadani, S., 2017. Source parameters of the 27th of June 2015 Gulf of Aqaba earthquake. Journal of Seismology, 21(5), pp.1055-1066.

Badawy, A. and Horváth, F., 1999. Recent stress field of the Sinai subplate region. Tectonophysics, 304(4), pp.385-403.

Badreldin, H., Toni, M. and El-Faragawy, K., 2019. Moment tensor inversion of small-tomoderate size local earthquakes in Egypt. Journal of African Earth Sciences, 151, pp.153172.

Bartov, Y., Steinitz, G., Eyal, M. and Eyal, Y., 1980. Sinistral movement along the Gulf of Aqaba-its age and relation to the opening of the Red Sea. Nature, 285(5762), p.220.

Ben-Avraham, Z. and Tibor, G., 1993. The northern edge of the Gulf of Elat. Tectonophysics, 226(1-4), pp.319-331.

Ben-Avraham, Z. and Zoback, M.D., 1992. Transform-normal extension and asymmetric basins: An alternative to pull-apart models. Geology, 20(5), pp.423-426.

BenAvraham, Z., 1985. Structural framework of the Gulf of Elat (Aqaba), northern Red Sea. Journal of Geophysical Research: Solid Earth, 90(B1), pp.703-726.

Ben-Avraham, Z., Hartnady, C.J.H. and Kitchin, K.A., 1997. Structure and tectonics of the Agulhas-Falkland fracture zone. Tectonophysics, 282(1-4), pp.83-98.

Bosworth, W., Huchon, P. and McClay, K., 2005. The red sea and gulf of Aden basins. Journal of African Earth Sciences, 43(1-3), pp.334-378. 
El Khrepy, S., Koulakov, I., Al-Arifi, N., Petrunin, A.G., 2016. Seismic structure beneath the Gulf of Aqaba and adjacent areas based on the tomographic inversion of regional earthquake data, Solid Earth 7(3), 965-978.

El-Nader, I.A., Hussein, H.M., 2018. The present-day active deformation in the central and northern parts of the Gulf of Suez area, Egypt, from earthquake focal mechanism data. Natural Hazards, 92(3), 1355-1369.

Freund, R., Zak, I. and Garfunkel, Z.W.I., 1968. Age and rate of the sinistral movement along the Dead Sea Rift. Nature, 220(5164), p.253.

Freund, R., Garfunkel, Z., Zak, I., Goldberg, M., Weissbrod, T., Derin, B., Bender, F., Wellings, F.E. and Girdler, R.W., 1970. The shear along the Dead Sea rift. Philosophical Transactions for the Royal Society of London. Series A, Mathematical and Physical Sciences, pp.107-130.

Garson, M.S., Krs, M., 1976. Geophysical and geological evidence of the relationship of Red Sea transverse tectonics to ancient fractures. Bull. Geol. Soc. Am. 87, 169-181.

Garfunkel, Z., 1981. Internal structure of the Dead Sea leaky transform (rift) in relation to plate kinematics. Tectonophysics, 80(1-4), pp.81-108.

Girdler, R.W., 1966. In: The Role of Translational and Rotational Movement in the Formation of the Red Sea and Gulf of Aden: Proceed. Sym. World Rift Systems, Ottawa 1965. Geol. Sur. Canada Paper, pp. 65e77, 66-14.

Hofstetter, A., 2003. Seismic observations of the 22/11/1995 Gulf of Aqaba earthquake sequence. Tectonophysics, 369(1-2), pp.21-36.

Hussein, H.M., Elenean, K.A., Marzouk, I.A., Korrat, I.M., El-Nader, I.A., Ghazala, H. and ElGabry, M.N., 2013. Present-day tectonic stress regime in Egypt and surrounding area based on inversion of earthquake focal mechanisms. Journal of African Earth Sciences, 81, pp.1-15.

Jackson, J. and McKenzie, D., 1988. The relationship between plate motions and seismic moment tensors, and the rates of active deformation in the Mediterranean and Middle East. Geophysical Journal International, 93(1), pp.45-73.

Jestin, F., Huchon, P. and Gaulier, J.M., 1994. The Somalia plate and the East African Rift System: present-day kinematics. Geophysical Journal International, 116(3), pp.637-654.

Lyberis, N., 1988. Tectonic evolution of the Gulf of Suez and the Gulf of Aqaba. Tectonophysics 153, 209-220.

Kiratzi, A.A. and Papazachos, C.B., 1995. Active crustal deformation from the Azores triple junction to the Middle East. Tectonophysics, 243(1-2), pp.1-24.

Kiratzi, A.A. and Langston, C.A., 1991. Moment tensor inversion of the 1983 January 17 Kefallinia event of Ionian islands (Greece). Geophysical Journal International, 105(2), pp.529-535. 
Kiratzi, A.A., 1993. A study on the active crustal deformation of the North and East Anatolian Fault Zones. Tectonophysics, 225(3), pp.191-203.

Klinger, Y., Rivera, L., Haessler, H., Maurin, J.-C., 1999. Active faulting in the Gulf of Aqaba: new knowledge from the Mw 7.3 Earthquake of 22 November 1995. Bull. Seismol. Soc. Am. 89, 1025-1036.

Kostrov, V.V., 1974. Seismic moment and energy of earthquakes, and seismic flow of rock. Izv. Acad. Sci. USSR Phys. Solid Earth, 1, pp.23-44.

Makovsky, Y., Wunch, A., Ariely, R., Shaked, Y., Rivlin, A., Shemesh, A., Avraham, Z.B. and Agnon, A., 2008. Quaternary transform kinematics constrained by sequence stratigraphy and submerged coastline features: the Gulf of Aqaba. Earth and Planetary Science Letters, 271(1-4), pp.109-122.

McCloskey, J., Nalbant, S.S., Steacy, S., Nostro, C., Scotti, O. and Baumont, D., 2003. Structural constraints on the spatial distribution of aftershocks. Geophysical research letters, 30(12).

Mahmoud S., Reilinger R., McClusky S., Vernant P. and Tealeb A., 2005. GPS evidence for northward motion of the Sinai block: implications for E. Mediterranean tectonics. Earth Planet. Sci. Lett., 238, 217-227.

Mohamed, E. K., Hassoup, A., Abou Elenean, K. M., OthmanAdel,_A. A., \& Hamed DiaaEldin, M. K. (2015). Earthquakes focal mechanism and stress field pattern in the northeastern part of Egypt. NRIAG Journal of Astronomy and Geophysics, 4(2), 205-221.

Molnar, P., 1979. Earthquake recurrence intervals and plate tectonics. Bulletin of the Seismological Society of America, 69(1), pp.115-133.

Papanikolaou, I. D., G. P. Roberts, and A. M. Michetti (2005), Fault scarps and deformation rates in Lazio-Abruzzo, central Italy: Comparison between geological fault slip-rate and GPS data, Tectonophysics, 408, 147-176.

Papazachos, C.B. and Kiratzi, A.A., 1992. A formulation for reliable estimation of active crustal deformation and its application to central Greece. Geophysical Journal International, 111(3), pp.424-432.

Quennell, A.M., 1959. Tectonics of the Dead Sea rift. In Proceedings of the 20th international geological congress, Mexico (Vol. 385, p. 403).

Reilinger, R., McClusky, S., Vernant, P., Lawrence, S., Ergintav, S., Cakmak, R., Ozener, H., Kadirov, F., Guliev, I., Stepanyan, R. and Nadariya, M., 2006. GPS constraints on continental deformation in the Africa-Arabia-Eurasia continental collision zone and implications for the dynamics of plate interactions. Journal of Geophysical Research: Solid Earth, 111(B5).

Salamon, A., Hofstetter, A., Garfunkel, Z. and Ron, H., 1996. Seismicity of the eastern Mediterranean region: perspective from the Sinai subplate. Tectonophysics, 263(1-4), pp.293-305. 
Salamon, A., Hofstetter, A., Garfunkel, Z. and Ron, H., 2003. Seismotectonics of the Sinai subplate-the eastern Mediterranean region. Geophysical Journal International, 155(1), pp.149-173. 


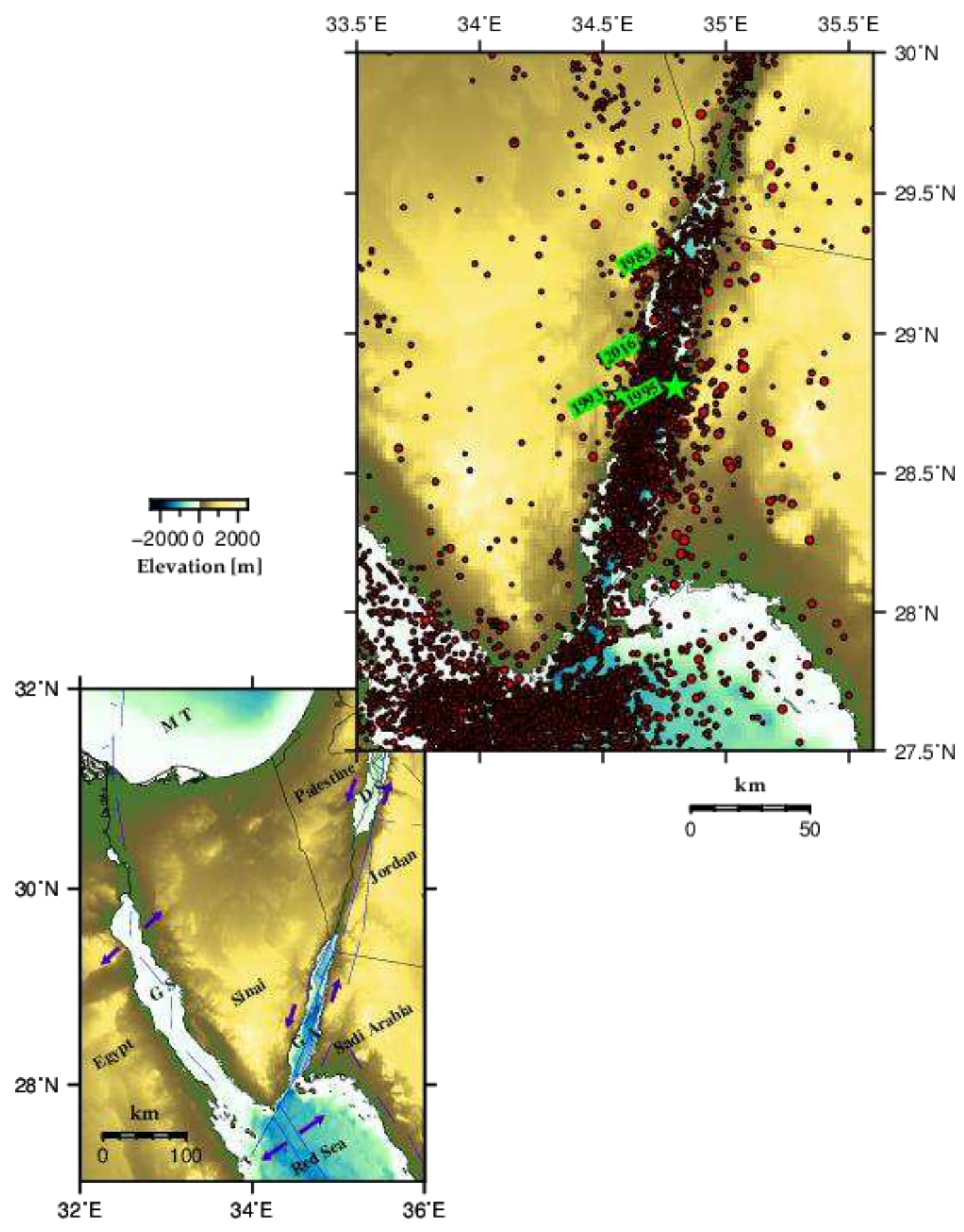

Figure 1 A map showing the seismicity in the Gulf of Aqaba from 1964 to 2019 (red circles). The distinctive earthquake sequences that occurred in 1983, 1993, 1995, 2015, and 2016 are shown (green stars). The arrows reflect the tectonic environments acting in the Gulf of Aqaba, Gulf of Suez, and the mostnorth part of the Red Sea. 


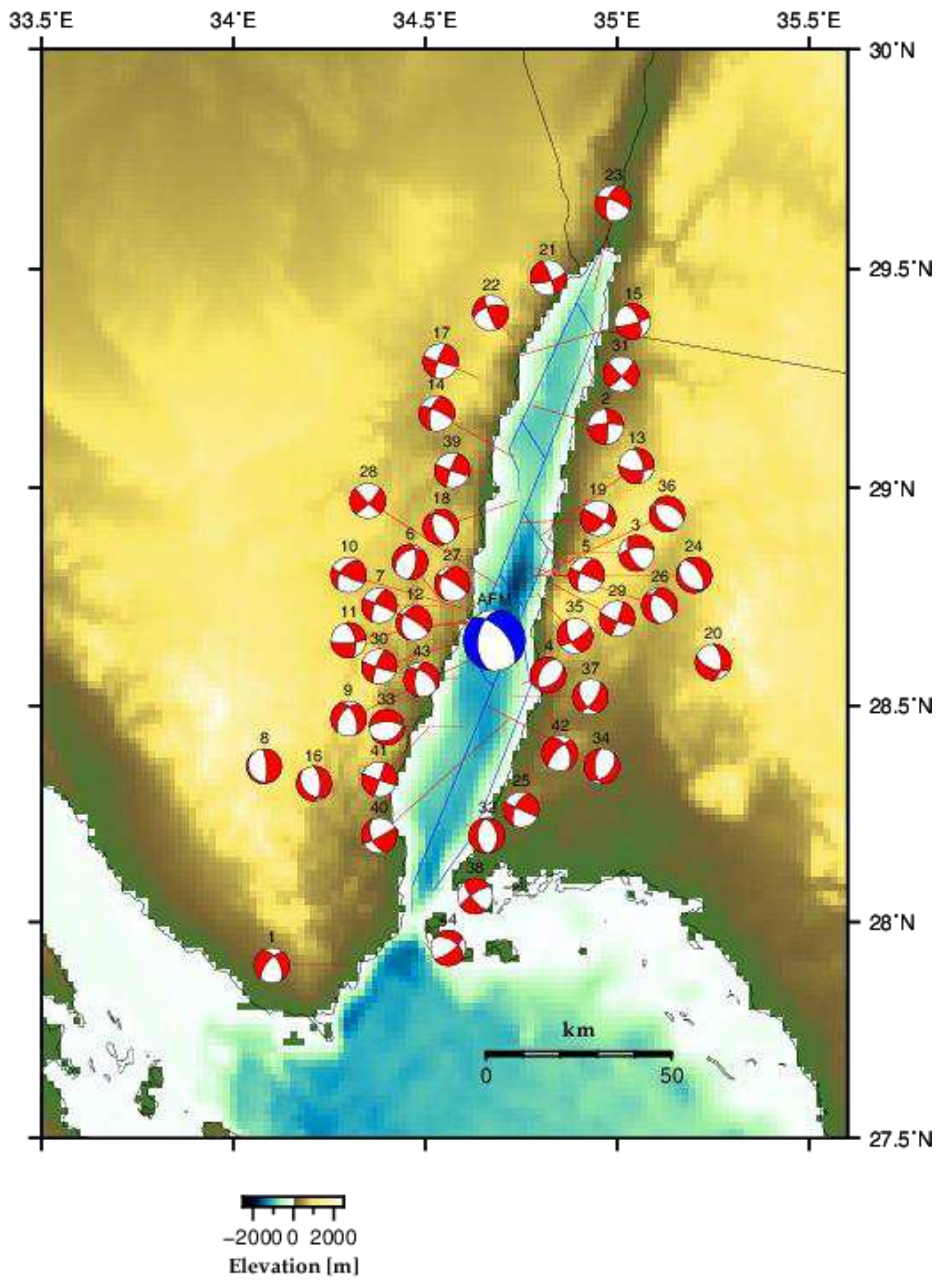

Figure 2 A map showing the focal mechanism solutions (red bach balls) listed in Table 1. The numbers refer to the ID in Table 1. The average fault plane solution (blue bach ball) obtained from moment tensor summation is also shown. 


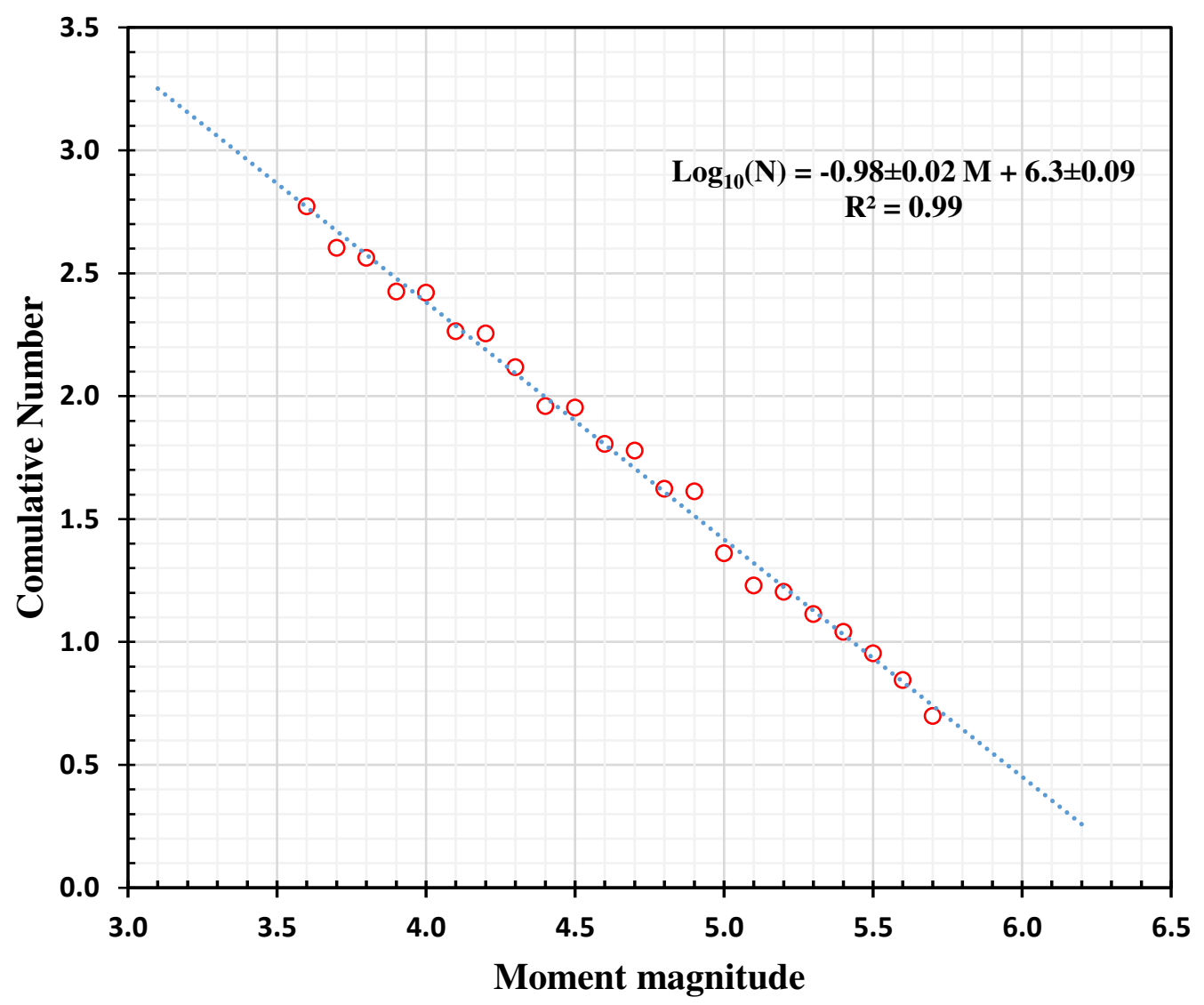

Figure 3 A graph showing the adopted magnitude-frequency distribution in the Gulf of Aqaba for the moment magnitude of completeness of $3.6 \pm 0.14$. The relationship was calculated using the maximum likelihood technique and uncertainties were determined using bootstrapping statistical technique. 
Table 1 The fault plane parameters of earthquakes used in the present analysis.

\begin{tabular}{|c|c|c|c|c|c|c|c|c|c|c|}
\hline No. & Date & Time & Lat. & Long. & Depth & Mag & strike & $\operatorname{dip}$ & rake & References \\
\hline 1 & 19820323 & 104800 & 27.9 & 34.3 & 10 & 4.7ML & 220 & 65 & -40 & Salamon et al. (2003) \\
\hline 2 & 19830203 & 134604.94 & 29.19 & 34.77 & 24 & $5.3 \mathrm{Mw}$ & 360 & 80 & 14 & Badawy \& Horvath (1999) \\
\hline 3 & 19851231 & 194241.00 & 28.85 & 35.05 & 09.00 & $4.8 \mathrm{ML}$ & 155.00 & 60.00 & -030.00 & Salamon et al. (2003) \\
\hline 4 & 19890909 & 000000.00 & 28.57 & 34.82 & 10.00 & 4.1ML & 205.00 & 50.00 & -110.00 & Salamon et al. (2003) \\
\hline 5 & 19930703 & 233410.00 & 28.86 & 34.82 & 18.00 & 4.7ML & 114.17 & 88.69 & 149.41 & Hussein et al. (2013) \\
\hline 6 & 19930803 & 004305.00 & 28.73 & 34.55 & 17.00 & $6.0 \mathrm{Mw}$ & 007.00 & 62.00 & -117.00 & ISC \\
\hline 7 & 19930803 & 124305.00 & 28.73 & 34.55 & 17.00 & $6.0 \mathrm{ML}$ & 293.54 & 87.27 & -157.17 & Hussein et al. (2013) \\
\hline 8 & 19930803 & 163323.00 & 28.36 & 34.08 & 15.00 & $5.7 \mathrm{ML}$ & 356.13 & 79.41 & -082.81 & Hussein et al. (2013) \\
\hline 9 & 19930807 & 045540.00 & 28.61 & 34.63 & 10.00 & $4.2 \mathrm{ML}$ & 216.57 & 50.19 & -042.41 & Hussein et al. (2013) \\
\hline 10 & 19930820 & 230959.00 & 28.72 & 34.61 & 02.00 & $4.6 \mathrm{ML}$ & 116.24 & 79.84 & 140.06 & Hussein et al. (2013) \\
\hline 11 & 19931103 & 183932.00 & 28.70 & 34.65 & 07.00 & 4.9ML & 086.20 & 76.13 & -148.33 & Hussein et al. (2013) \\
\hline 12 & 19931108 & 010602.00 & 28.69 & 34.65 & 08.00 & $4.7 \mathrm{ML}$ & 303.34 & 80.49 & -119.89 & Hussein et al. (2013) \\
\hline 13 & 19931204 & 233411.00 & 28.89 & 34.80 & 10.00 & 4.6ML & 093.21 & 68.07 & -147.59 & Hussein et al. (2013) \\
\hline 14 & 19951122 & 001526.00 & 29.07 & 34.73 & 18.00 & $7.2 \mathrm{Mw}$ & 196.00 & 59.00 & -015.00 & ISC \\
\hline 15 & 19951122 & 124704.00 & 29.30 & 34.74 & 15.00 & $5.0 \mathrm{ML}$ & 073.99 & 80.04 & -150.11 & Hussein et al. (2013) \\
\hline 16 & 19951122 & 221657.00 & 28.32 & 34.21 & 15.00 & $5.2 \mathrm{ML}$ & 357.43 & 60.54 & -068.49 & Hussein et al. (2013) \\
\hline 17 & 19951123 & 000717.00 & 29.25 & 34.64 & 10.00 & $5.7 \mathrm{Mw}$ & 199.00 & 77.00 & 007.00 & Harvard CMT \\
\hline 18 & 19951124 & 164345.00 & 28.97 & 34.74 & 10.00 & 4.9ML & 164.49 & 54.28 & -068.04 & Hussein et al. (2013) \\
\hline 19 & 19951211 & 013208.00 & 28.92 & 34.75 & 19.00 & $5.0 \mathrm{ML}$ & 302.00 & 84.00 & 146.79 & Hussein et al. (2013) \\
\hline 20 & 19960103 & 100526.00 & 28.60 & 35.25 & 10.00 & $4.8 \mathrm{ML}$ & 113.43 & 59.77 & -137.83 & Hussein et al. (2013) \\
\hline 21 & 19960108 & 001318.00 & 29.38 & 34.82 & 06.00 & $3.8 \mathrm{ML}$ & 339.96 & 78.86 & 164.20 & Hussein et al. (2013) \\
\hline 22 & 19960116 & 061700.00 & 29.34 & 34.73 & 06.00 & $4.3 \mathrm{ML}$ & 158.64 & 82.79 & 148.51 & Hussein et al. (2013) \\
\hline 23 & 19960204 & 072300.00 & 29.45 & 34.94 & 06.00 & $3.6 \mathrm{ML}$ & 293.84 & 77.43 & -148.50 & Hussein et al. (2013) \\
\hline 24 & 19960221 & 005951.00 & 28.80 & 34.78 & 10.00 & $5.3 \mathrm{Mw}$ & 132.00 & 30.00 & -104.00 & Harvard CMT \\
\hline 25 & 19970510 & 000147.00 & 28.26 & 34.70 & 10.00 & $4.6 \mathrm{Mw}$ & 114.00 & 89.00 & 150.00 & ISC \\
\hline 26 & 20000308 & 142226.00 & 28.83 & 34.73 & 15.00 & $4.9 \mathrm{Mw}$ & 182.00 & 48.00 & -048.00 & ISC \\
\hline 27 & 20000308 & 122229.00 & 28.64 & 34.57 & 10.00 & $4.8 \mathrm{Mw}$ & 198.00 & 31.00 & -018.00 & ISC \\
\hline
\end{tabular}




\begin{tabular}{|c|c|c|c|c|c|c|c|c|c|c|}
\hline 28 & 20000308 & 142225.00 & 28.77 & 34.70 & 07.00 & 4.9ML & 134.95 & 85.10 & -169.32 & Hussein et al. (2013) \\
\hline 29 & 20000406 & 063734.00 & 28.78 & 34.83 & 12.00 & $4.8 \mathrm{ML}$ & 019.99 & 85.10 & -012.08 & Hussein et al. (2013) \\
\hline 30 & 20000803 & 142225.00 & 28.64 & 34.57 & 10.00 & $4.8 \mathrm{ML}$ & 107.59 & 82.31 & 166.45 & Hussein et al. (2013) \\
\hline 31 & 20010207 & 033900.00 & 29.26 & 35.01 & 21.00 & $3.6 \mathrm{Mw}$ & 044.00 & 80.00 & -005.00 & ISC \\
\hline 32 & 20021110 & 005945.00 & 28.23 & 34.62 & 16.00 & 3.9ML & 180.27 & 47.30 & -083.94 & Hussein et al. (2013) \\
\hline 33 & 20040922 & 120023.00 & 28.45 & 34.60 & 10.30 & $3.2 \mathrm{ML}$ & 270.22 & 64.05 & -076.21 & Hussein et al. (2013) \\
\hline 34 & 20050120 & 134100.00 & 28.50 & 34.66 & 18.80 & $3.2 \mathrm{ML}$ & 041.00 & 43.00 & -056.00 & Mohamed et al. (2015) \\
\hline 35 & 20080302 & 170600.00 & 28.76 & 34.79 & 13.70 & $3.2 \mathrm{ML}$ & 058.00 & 75.00 & -029.00 & Mohamed et al. (2015) \\
\hline 36 & 20080404 & 140500.00 & 28.78 & 34.75 & 06.90 & 3.7ML & 145.00 & 46.00 & -067.00 & Mohamed et al. (2015) \\
\hline 37 & 20111021 & 123700.00 & 28.52 & 34.73 & 09.00 & 3.7ML & 148.00 & 49.00 & -147.00 & Abdel-Aal \& Badreldin (2016) \\
\hline 38 & 20130610 & 084400.00 & 28.06 & 34.63 & 06.10 & 3.9ML & 142.00 & 73.00 & -015.00 & Abdel-Aal \& Badreldin (2016) \\
\hline 39 & 20150627 & 053404.00 & 29.04 & 34.67 & 22.00 & $5.6 \mathrm{Mw}$ & 200.00 & 82.00 & 002.00 & Harvard CMT \\
\hline 40 & 20160516 & 014200.00 & 28.47 & 34.72 & 07.35 & $4.3 \mathrm{ML}$ & 157.00 & 52.00 & -173.00 & Ali \& Badreldin (2019) \\
\hline 41 & 20160516 & 004559.00 & 28.45 & 34.51 & 18.00 & $5.2 \mathrm{Mw}$ & 019.00 & 88.00 & -003.00 & ISC \\
\hline 42 & 20160813 & 030600.00 & 28.49 & 34.82 & 19.10 & 3.9ML & 332.00 & 47.00 & -153.00 & Ali \& Badreldin (2019) \\
\hline 43 & 20161129 & 000113.00 & 28.56 & 34.59 & 18.00 & $4.7 \mathrm{Mw}$ & 188.00 & 59.00 & -044.00 & ISC \\
\hline 44 & 20170519 & 141600.00 & 27.94 & 34.56 & 03.55 & $4.1 \mathrm{ML}$ & 304.00 & 50.00 & -027.00 & Ali \& Badreldin (2019) \\
\hline
\end{tabular}




\section{Figures}

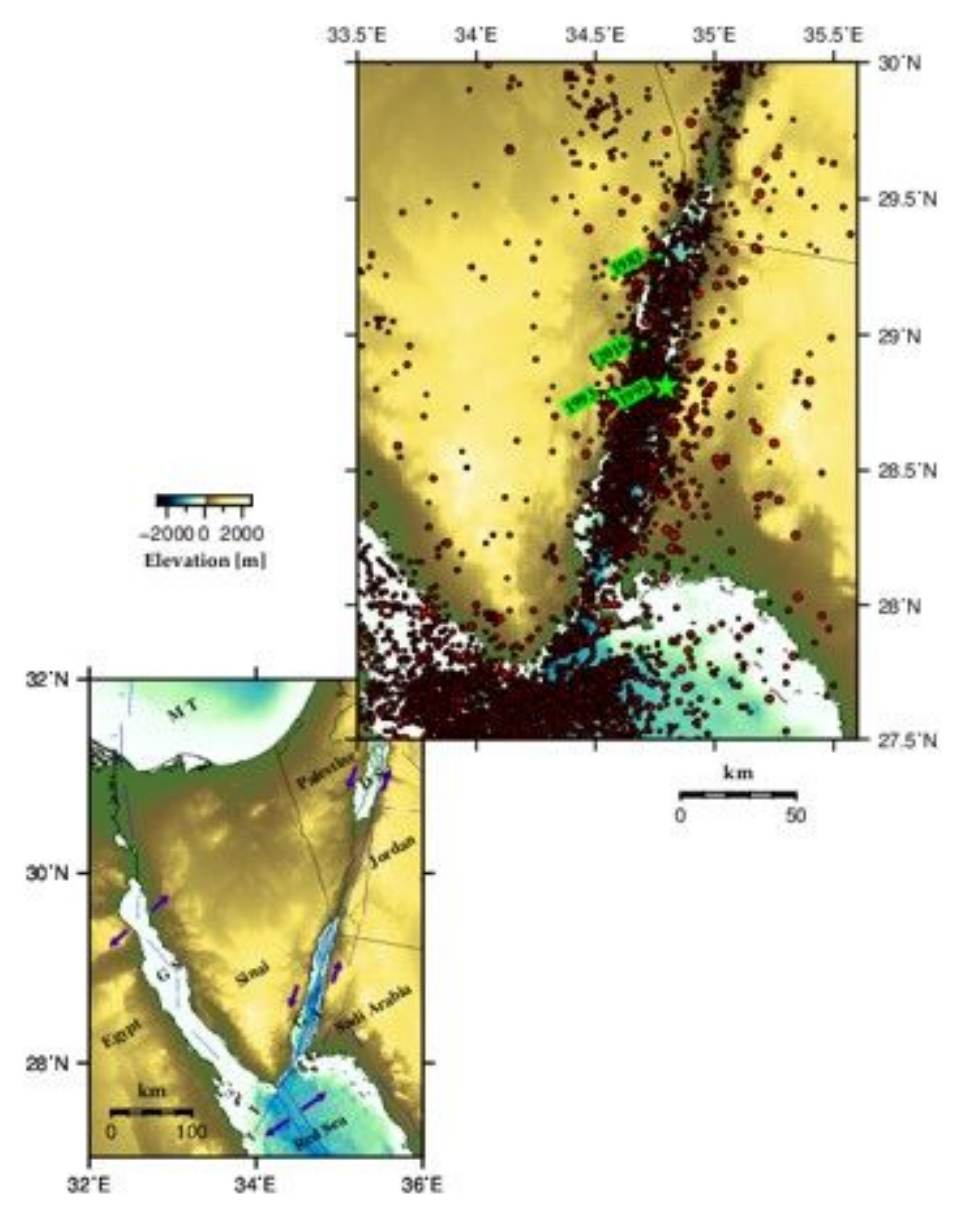

Figure 1

A map showing the seismicity in the Gulf of Aqaba from 1964 to 2019 (red circles). The distinctive earthquake sequences that occurred in 1983, 1993, 1995, 2015, and 2016 are shown (green stars). The arrows reflect the tectonic environments acting in the Gulf of Aqaba, Gulf of Suez, and the mostnorth part of the Red Sea. 


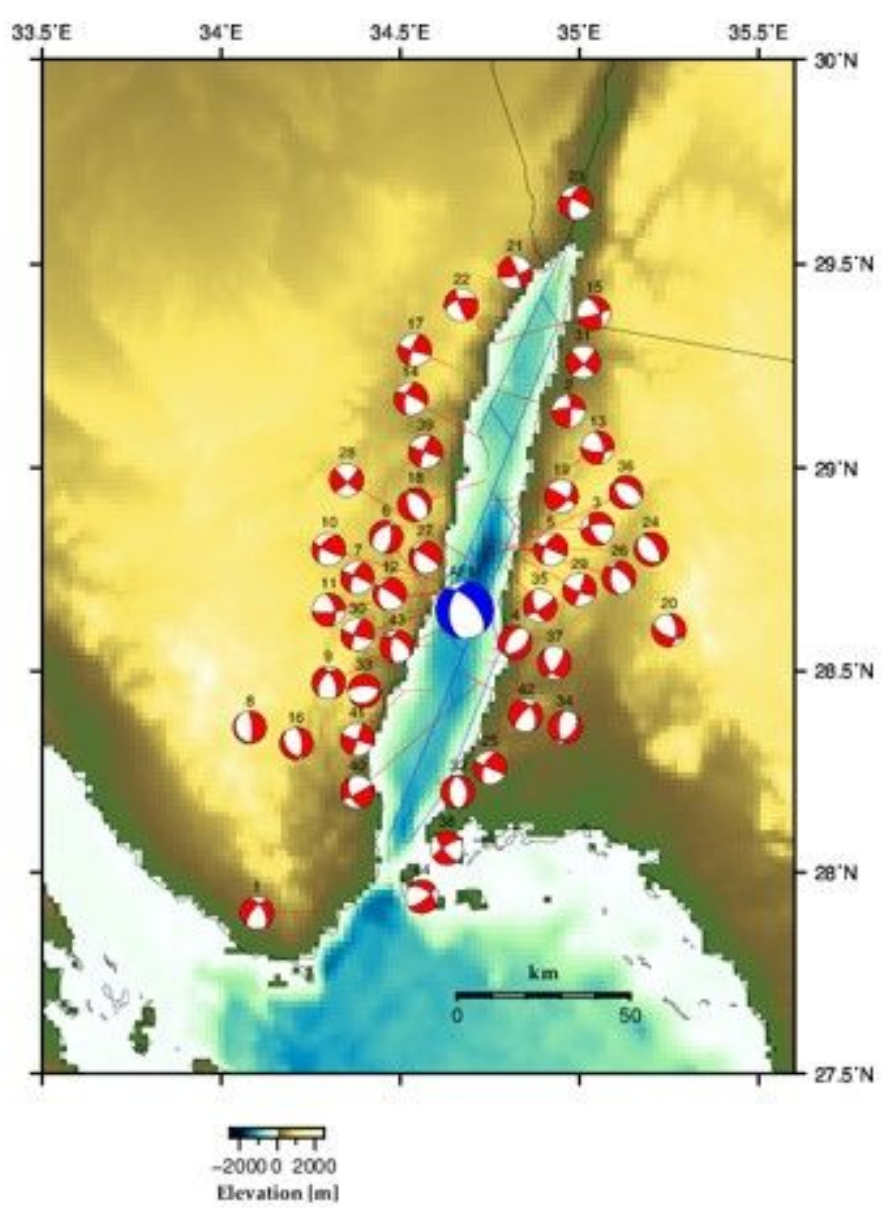

Figure 2

A map showing the focal mechanism solutions (red bach balls) listed in Table 1. The numbers refer to the ID in Table 1. The average fault plane solution (blue bach ball) obtained from moment tensor summation is also shown. 


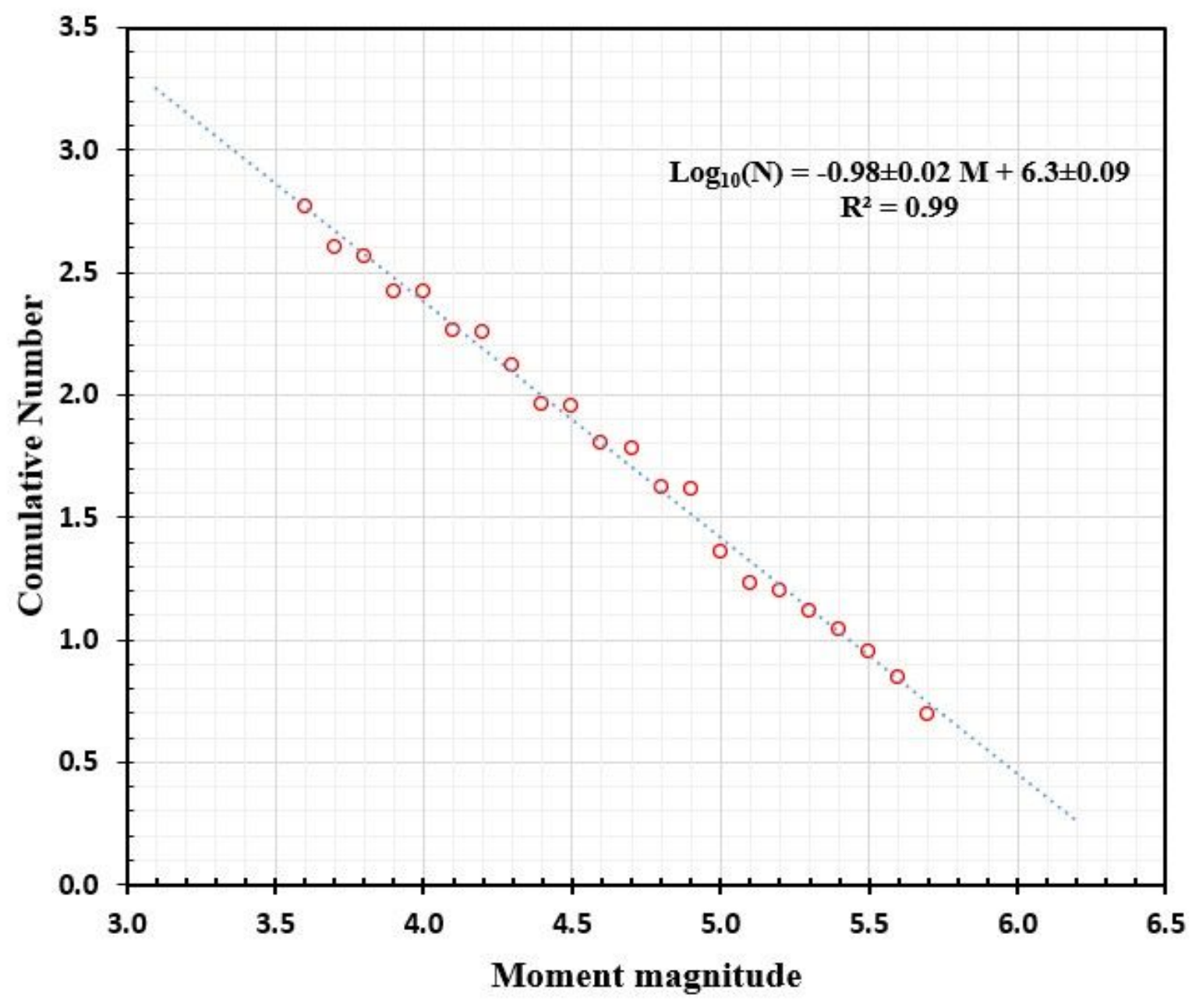

Figure 3

A graph showing the adopted magnitude-frequency distribution in the Gulf of Aqaba for the moment magnitude of completeness of $3.6 \pm 0.14$. The relationship was calculated using the maximum likelihood technique and uncertainties were determined using bootstrapping statistical technique.

\section{Supplementary Files}

This is a list of supplementary files associated with this preprint. Click to download.

- Gabstract.jpg 